\title{
Pengaruh Ekstrak Daun Kecibeling (Strobilanthes crispa), Kayu Manis (Cinnamon), dan Kersen (Muntingia calabura) Terhadap Indeks Glikemik pada Pengolahan Beras Metode Pratanak
}

\author{
Margono*, Louise, Laila Zulhijah Choirudina, Ameilia Ayu Safitri, dan Fawnia Hanifah \\ Program Studi Teknik Kimia, Universitas Sebelas Maret Surakarta \\ *E-mail: margono@ft.uns.ac.id (Corresponding author)
}

\begin{abstract}
Diabetes mellitus is a top five deadly disease in Indonesia. A healthy diet with consuming low sugar index food is suggested to prevent diabetes mellitus. Rice as the main source of carbohydrate in Indonesia is categorized as food with a high glycemic index. This study is experimenting rice with a low glycemic index that suitable to be consumed by diabetes mellitus sufferer. Various extracts are used in the making of low glycemic index rice such as strobilanthes crispus, cinnamon, and muntingia calabura. The rice is marinated with $1 \%$ extract for 2 hours and continued to cook in an autoclave for 15 minutes with temperature $116^{\circ} \mathrm{C}$. The rice then dried in an oven at $50^{\circ} \mathrm{C}$ for 24 hours before it cooked in a rice cooker and can be consumed. The result shows that strobilanthes crispus and cinnamon extract rice has lower glycemic index than common rice.
\end{abstract}

Keywords: diabetes mellitus, rice, glycemic index, strobilanthes crispus, Cinnamon, muntingia calabura

EQUILIBRIUM Volume 5 No.1 July 2021

Online at http://equilibrium.ft.uns.ac.id 


\section{Pendahuluan}

Diabetes merupakan jenis gangguan metabolisme yang ditandai dan diidentifikasi oleh adanya hiperglikemia tanpa adanya pengobatan [1]. Diabetes Mellitus (DM) merupakan penyakit serius yang terjadi ketika tubuh tidak memproduksi cukup insulin atau tidak dapat menggunakan secara efektif insulin yang diproduksi [2]. Diabetes diklasifikasikan menjadi 2 tipe, yaitu DM tipe 1 berhubungan dengan keturunan dan DM tipe 2 disebabkan oleh gaya hidup tidak sehat. Jenis DM yang banyak ditemui di indonesia adalah DM tipe 2 yaitu sekitar 90\%-95\% dari seluruh kasus DM. Pada DM tipe 2, pankreas masih berfungsi menghasilkan insulin, tetapi kualitas insulin yang dihasilkan kurang baik karena tidak berfungsinya reseptor glukosa untuk mengikat glukosa dalam darah, sehingga glukosa dalam darah meningkat [3].

Resiko diabet sering dikaitkan dengan pangan sumber karbohidrat yang bernilai Indeks Glikemik (IG) rendah. IG adalah angka yang menunjukkan perbandingan antara luas daerah di bawah kurva respon glukosa darah $50 \mathrm{~g}$ karbohidrat pangan uji dan luas daerah di bawah kurva respon glukosa darah $50 \mathrm{~g}$ karbohidrta pangan acuan (biasanya berupa glukosa atau roti tawar) yang diujikan pada orang yang sama pada rentang waktu 2 jam setelah konsumsi [4]. Masing-masing komponen bahan pangan memberikan kontribusi dan saling berpengaruh hingga menghasilkan respons glikemik tertentu [5]. Dengan demikian, konsumsi sumber karbohidrat ber-IG rendah menjadi salah satu solusi untuk mengendalikan kadar glukosa darah agar tidak naik secara cepat. Diet beras ber-IG rendah menjadi alternatif di Indonesia yang penduduknya mengkonsumsi beras sebagai makanan pokoknya.

Beras selama ini dikenal sebagai pangan yang memiliki IG tinggi atau bersifat hiperglikemik. Sifat beras ini yang mengakibatkan kadar glukosa darah dapat meningkat dengan cepat. Hal ini yang menyebabkan jumlah konsumsi beras atau nasi dibatasi untuk terapi diet pada penderita DM. IG berbagai beras sangat bervariasi, antara lain varietas IR36, Taj Mahal, Batang Piaman, dan Mekongga berturut-turut memiliki IG sebesar 45, 60, 86, dan 96 [6]. Pengolahan beras metode pratanak terbukti dapat menurunkan indeks glikemik beras [5]. Hasil perlakuan pratanak selama 20 menit pada tekanan pengukusan $2,0 \mathrm{~kg} / \mathrm{cm}^{2}\left(127^{\circ} \mathrm{C}\right) \mathrm{mampu}$ menurunkan indek glikemik dari 48,18 menjadi 35,52 dan tekanan pengukusan $0,8 \mathrm{~kg} / \mathrm{cm}^{2}\left(110^{\circ} \mathrm{C}\right)$ mampu menurunkan indeks glikemik dari 48,18 menjadi 44,88. Gabah hasil pengolahan pratanak dapat disimpan atau langsung digiling menjadi beras pratanak yang siap dikonsumsi.

Upaya rekayasa nilai IG pada beras dapat dilakukan pula menggunakan ekstrak daun teh hijau. Teh hijau mengandung senyawa polifenol yang berfungsi sebagai antioksidan dapat menurunkan aktivitas enzim amilase dan tripsin [7]. Pengolahan beras metode pratanak menggunakan polisakarida teh hijau alami terbukti terjadi penghambatan pembentukan gula reduksi selama 120 menit pengujian, yaitu turun dari $80,25 \%$ untuk beras tanpa teh hijau menjadi 66,23\% untuk beras pratanak menggunakan teh hijau [8]. Penghambatan ini terjadi karena adanya kandungan enzim amylase dan glukosidase yang dianggap efektif dalam mengontrol glukosa darah dan juga kandungan senyawa katekin dan polifenol yang mampu menghambat pemecahan karbohidrat menjadi bentuk yang paling sederhana (glukosa) yang bisa diserap oleh tubuh. Pengujian lain dilakukan dalam proses pembuatan beras instan fungsional dengan memanfaatkan ekstrak teh hijau dapat menurunkan daya cerna pati in vitro dan indeks glikemiknya dari 67 menjadi 49, sehingga berpotensi sebagai diet bagi penderita diaberes melitus [5]. Pengolahan beras dilakukan dengan cara perendaman beras dalam ekstrak daun teh hijau 4\% selama 2 jam dengan perbandingan beras : ekstrak $=1: 1$, pemanasan pada tekanan $80 \mathrm{kPa}$ selama 10 menit, pendinginan pada suhu $-4^{\circ} \mathrm{C}$ selama $24 \mathrm{jam}$, dan pendinginan pada suhu $60^{\circ} \mathrm{C}$ selama 4 jam. Turunnya nilai IG tersebut diduga karena kandungan polifenol dalam daun teh hijau. Polifenol dalam teh hijau (katekin, epikatekin, dan Epiglokatekin galat) bersifat antioksidan. Polifenol mempunyai kemampuan menangkap radikal bebas seperti peroksinitrit (ONNO-) dan superoksida (O2-) [9]. Konsumsi teh hijau secara rutin dapat mencegah timbulnya penyakit DM tipe 2 [10].

Kandungan polifenol dalam daun teh yang dapat digunakan untuk mengontrol kadar glukosa darah juga ditemukan dalam tanaman lain, yaitu daun kecibeling (Strobilanthes crispa Blume) dan kayu manis (cinnamomum cassia). Daun kecibeling di antaranya dapat digunakan untuk menurunkan kadar kolesterol, peluruh air seni (diuretik), antidiabetes, wasir, tumor, maag, menghancurkan batu empedu, batu ginjal, dan batu kandung kemih [11]. Kandungan senyawa pada kecibeling di antaranya polifenol, flavonoid, katekin, alkanoid, tannin, dan $\beta$-sitosterol [12]. Adapun senyawa bioaktif yang terdapat dalam kayu manis adalah asam cinnamat, cinnamaldehid, polifenol dan flavonoid. Beberapa penelitian mengatakan bahwa cinnamaldehid memiliki efek meningkatkan transport glukosa oleh GLUT 4 pada sel adiposa dan otot skeletal sehingga dapat menurunkan glukosa darah [13]. Asam cinnamat dapat menghambat enzim HMG-CoA reduktase hepar dan menurunkan peroksidasi lipid di hepar [14]. Kandungan lain seperti polifenol dapat mengaktifkan reseptor 
insulin dengan cara meningkatkan aktifitas fosforolasi insulin dan menghambat protein tyrosine phosphatase1(PTP-1) yang akan menurunkan aktifitas reseptor insulin di jaringan adiposa [15].

Daun kersen (Muntingia calabura) merupakan salah satu tumbuhan yang diduga mengandung bahan aktif yang berkhasiat sebagai penurun gula dalam darah. Hasil uji fitokimia pendahuluan terhadap ekstrak metanol daun kersen diketahui mengandung senyawa metabolit sekunder golongan flavonoid, triterpenoid, tannin, saponin, dan steroid [16]. Studi pengaruh pemberian ekstrak daun kersen terhadap penurunan kadar glukosa darah pada tikus putih (Rattus norvegicus) dengan metode induksi aloksan menunjukkan bahwa dosis $0,4 \mathrm{~g} / \mathrm{kg}$ BB dapat menurunkan kadar gula darah tikus putih sebesar 26,51\% [17]. Daun kersen berperan sebagai anti oksidan yang menyekresi hormon insulin yang bekerja untuk metabolisme gula.

Penelitian ini adalah untuk melakukan studi pengolahan beras secara pratanak menggunakan ekstrak kayu manis, daun kecibeling, dan daun kersen pada beras ciherang. Efek respon konsumsi beras hasil pengolahan terhadap kadar glukosa darah dievaluasi dalam rangka mengukur IG beras tersebut. Studi lain yang juga dipelajari adalah pengaruh suhu dan lama pemasakan beras terhadap nilai IG beras hasil olahan.

\section{Metode Penelitian}

\subsection{Bahan}

Beras jenis Ciherang dibeli dalam bentuk gabah dari penggilingan padi Tegalrejo, Metuk, Kecamatan Mojosongo, Kabupaten Boyolali, Jawa Tengah. Aquades berasal dari Laboratorium MIPA Universitas Sebelas Maret Surakarta. Daun kecibeling diperoleh dari daerah Cilacap dan daun kersen diperoleh dari daerah Surakarta, sedangkan kayu manis dibeli dari Pasar Gede, Surakarta.

\subsection{Metode}

Bahan kering berupa kayu manis atau daun kecibeling atau daun kersen dihaluskan menggunakan blender dan diayak menggunakan ayakan 32 mesh. Bubuk bahan kering masing-masing diekstraksi menggunakan pelarut aquades pada suhu $95^{\circ} \mathrm{C}$ selama 8 menit sesuai dengan perbandingan yang diinginkan, yaitu $1 \% \mathrm{~b} / \mathrm{b}$ dan $3 \% \mathrm{~b} / \mathrm{b}$. Air ekstrak dipisahkan dari bagian padatan menggunakan kertas saring dan siap digunakan untuk proses pratanak.

Beras ciherang direndam dalam air ekstrak kayu manis 1\% pada suhu ruangan selama 2 jam dengan perbandingan $1: 1 \mathrm{~b} / \mathrm{b}$. Beras yang sudah ditiriskan dimasak menggunakan otoklaf dalam wadah tertutup tanpa penambahan air pada suhu $116^{\circ} \mathrm{C}$ selama 15 menit. Berikutnya, beras dikeringkan pada suhu $50^{\circ} \mathrm{C}$ selama 24 jam dan proses pratanak selesai. Cara yang sama dilakukan untuk variabel pemasakan suhu $105^{\circ} \mathrm{C}$ dan $133^{\circ} \mathrm{C}$ selama 15 menit, serta $116^{\circ} \mathrm{C}$ selama 60 menit. Adapun variabel jenis ekstrak, pemasakan dilakukan pada suhu $116^{\circ} \mathrm{C}$ selama 15 menit.

\subsection{Uji Nilai Indeks Glikemik}

Kadar glukosa darah diukur oleh 2 orang responden dengan metode finger prick capillary blood samples menggunakan alat glucometer. Responden melakukan puasa selama 12 jam kecuali air puth kemudian diperiksa kadar glukosa darahnya sebagai kadar glukosa darah waktu 0 jam. Responden mengkonsumsi sampel yang mengandung $50 \mathrm{~g}$ karbohidrat. Porsi sampel dihitung dengan persamaan (1) [18].

$$
\text { Jumlah porsi sampel }(\mathrm{g})=\frac{50 \mathrm{~g} \times 100}{\text { kadar karbohidrat-kadar serat }}
$$

Beras ciherang per $100 \mathrm{~g}$ memiliki kadar karbohidrat 78,13 g dan serat pangan 6,38 g [19]. Maka, jumlah porsi konsumsi beras ekstrak sebesar 69,7 gram. Pemeriksaan kadar glukosa darah selama 2 jam pascakonsumsi sampel dilakukan setiap 30 menit (30, 60, 90, dan 120 menit). Pada hari yang berbeda responden melakukan hal yang sama dengan mengkonsumsi $50 \mathrm{~g}$ glukosa murni sebagai acuan. Kadar glukosa darah diplot dalam grafik kadar glukosa darah (y) fungsi waktu pascakonsumsi (x). Indeks glikemik (IG) dihitung menggunakan persamaan (2): 


$$
\text { Indeks glikemik }=\frac{\text { luas area dibawah kurva sampel }}{\text { luas area dibawah kurva glukosa murni }} \times 100
$$

\section{Hasil dan Pembahasan}

Pengolahan gabah pratanak memerlukan perendaman selama 4 jam pada suhu $60^{\circ} \mathrm{C}$ untuk mencapai kadar air sekitar 30\% [5], sedangkan perendaman pada suhu $30^{\circ} \mathrm{C}$ memerlukan waktu 48 jam untuk mendapatkan kadar air sebesar 29,41\% [20]. Lama waktu perendaman tersebut sangat dipengaruhi oleh keberadaan kulit gabah (sekam) yang kecepatan adsorbsinya lambat. Lama waktu perendaman jauh lebih cepat jika dilakukan pada gabah giling (beras), yaitu 0,5 jam perendaman pada suhu $30^{\circ} \mathrm{C}$ dapat meningkatkan kadar air dalam beras sehingga mencapai 30,6\%. Kadar air tersebut relatif konstan hingga 6 jam perendaman [21]. Pola kadar air perendaman beras tersebut ditunjukkan pada Gambar 1. Berdasarkan data tersebut maka lama perendaman beras pratanak dapat dilakukan berkisar antara 0,5 - 6 jam agar kadar air beras mencapai kadar air proses pratanak.

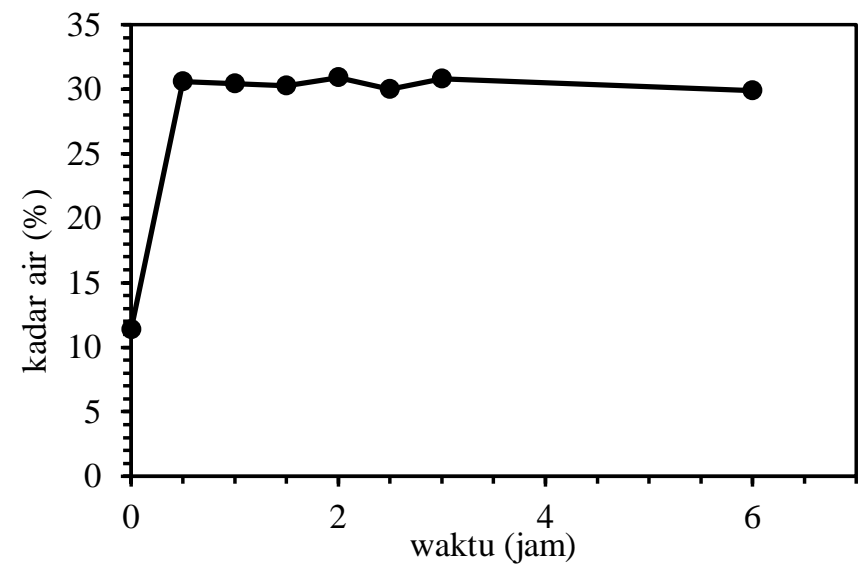

Gambar 1. Pengaruh Waktu Perendaman Terhadap Kadar Air Beras (Margono dkk, 2020)

Pengaruh suhu pemasakan dipelajari pada waktu pemasakan 15 menit menggunakan perendaman ekstrak kayu manis $1 \%$. Variasi suhu pemasakan dipilih pada $105^{\circ} \mathrm{C}, 116^{\circ} \mathrm{C}$, dan $133^{\circ} \mathrm{C}$. IG beras pratanak hasil pemasakan pada berbagai suhu disajikan pada Gambar 2.

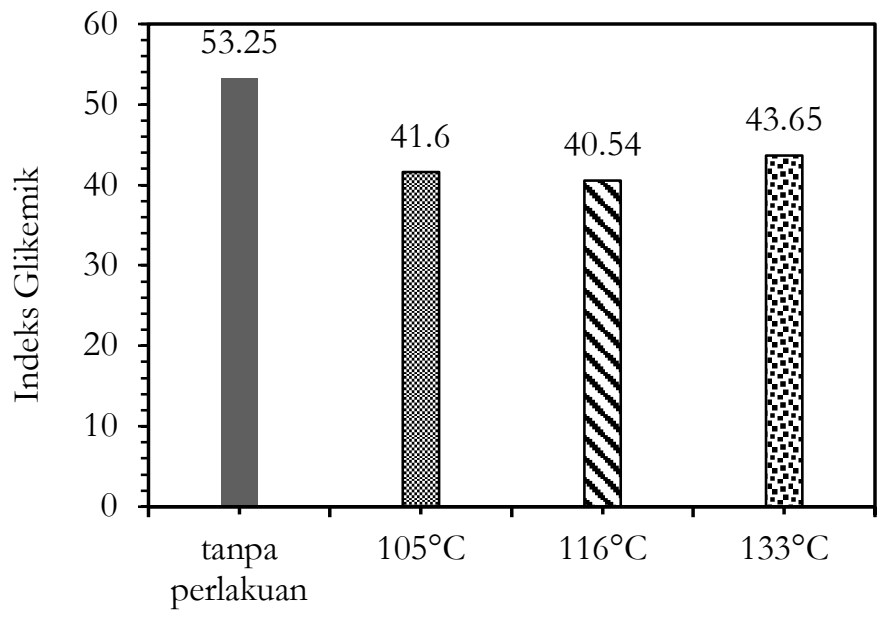

Suhu pemasakan

Gambar 2. Pengaruh Suhu Pemasakan Terhadap Indeks Glikemik Beras Pratanak (Ekstrak Kayu Manis $1 \%$, Waktu pemasakan 15 Menit) 
Gambar 2 menunjukkan bahwa proses pratanak menggunakan ekstrak kayu manis pada beras ciherang dapat menurunkan nilai IG rata-rata lebih dari 20\%. Namun demikian, Gambar 2 menunjukkan bahwa suhu pemasakan tidak menunjukkan pengaruh yang spesifik terhadap IG. Pemasakan pada suhu $105^{\circ} \mathrm{C}$ menghasilkan beras dengan IG 41,6 dan suhu pemasakan $116^{\circ} \mathrm{C}$ menurunkan IG menjadi 40,54. Namun, IG beras ciherang pratanak naik menjadi 43,65 ketika dimasak pada suhu $133^{\circ} \mathrm{C}$. Jadi, tidak ada pola tertentu pada studi pengaruh suhu pratanak dan perbedaan IG cukup kecil sehingga variasi suhu pratanak tidak menunjukkan pengaruh yang spesifik. Adapun studi pengaruh lama pemasakan terhadap IG dilakukan pada suhu $116^{\circ} \mathrm{C}$ menggunakan ekstrak kayu manis. Lama pemasakan dibandingkan antara 15 menit dan 60 menit. Hasil selengkapnya ditunjukkan pada Gambar 3.

Gambar 3 menunjukkan bahwa lama pemasakan 15 menit dapat menurunkan IG beras giling dari 54 menjadi 40,54. Namun demikian, IG menjadi lebih tinggi ketika pemasakan dilakukan 60 menit, yaitu IG naik menjadi 49. Hal ini diduga karena proses hidrasi (gelatinisasi) pati pada beras semakin sempurna ketika pemasakan semakin lama. Pati yang tergelatinasi membentuk granula yang mengembang dan memiliki permukaan kontak dengan enzim pencernaan yang luas. Semakin luas area permukaan semakin cepat terjadi reaksi dengan enzim [22]. Dengan demikian, nilai IG beras yang lebih lama dimasak akan lebih mudah dicerna sehingga IG semakin tinggi. Jadi, lama pemasakan 15 menit merupakan waktu pemasakan yang sesuai untuk permbuatan beras pratanak berindeks glikemik rendah.

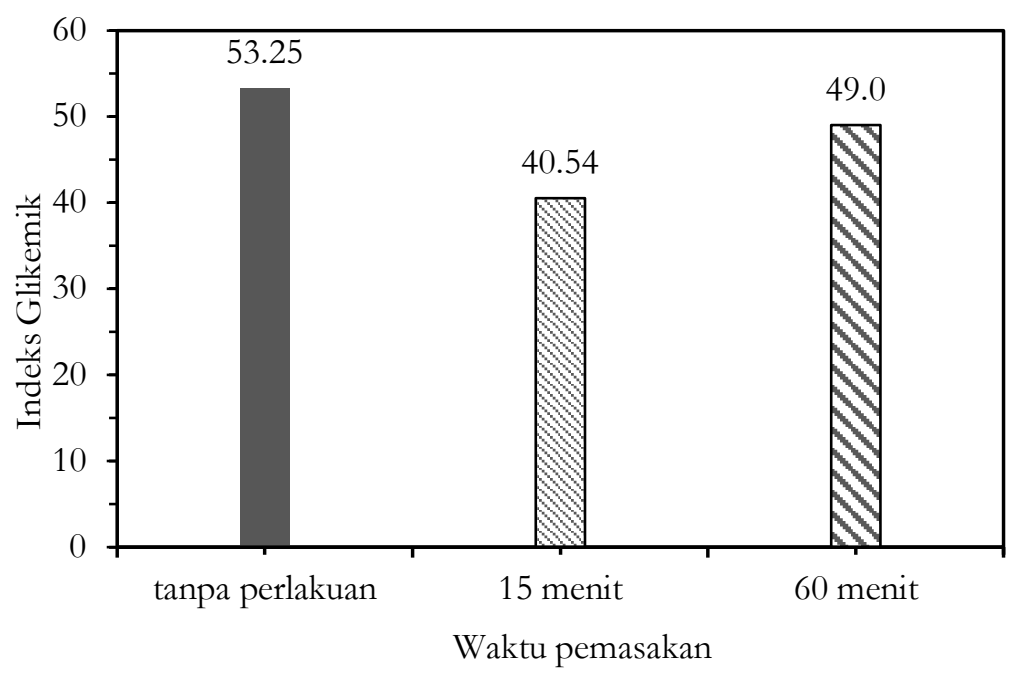

Gambar 3. Pengaruh Lama Pemasakan Terhadap Nilai Indeks Glikemik Beras Pratanak (Ekstrak Kayu Manis $1 \%$, Suhu Pemasakan $116^{\circ} \mathrm{C}$ )

Faktor lain yang mempengaruhi IG pada pangan antara lain adalah kadar serat, perbandingan amilosa dan amilopektin, daya cerna pati, kadar lemak dan protein, dan cara pengolahan. Kecibeling, kayu manis, dan kersen merupakan jenis tanaman yang mengandung flavonoid. Flavonoid dengan pati akan membentuk kompleks sehingga sisi atau bagian pati yang pada keadaan normal dihidrolisis oleh enzim pencernaan menjadi tidak dikenali sehingga kemampuan pati untuk dihidrolosis menurun [5]. Senyawa flavonoid juga menghambat enzim-enzim amliase dan tripsin. Pencernaan dan penyerapan karbohidrat yang lamban akan menghasilkan glukosa secara lambat sehingga memberikan aktivitas hipoglikemik. Dalam penelitian ini dipelajari pengaruh ekstrak daun kecibeling, kayu manis, dan daun kersen terhadap nilai IG beras pratanak. Bahan-bahan tersebut sudah dikenal sebagai bahan yang dapat digunakan untuk terapi penderita DM. Diharapkan manfaat tersebut dapat diperoleh jika digunakan dalam proses pembuatan beras pratanak. Hasil pengujian IG beras pratanak menggunakan beberapa ekstrak tersebut ditunjukkan pada Gambar 4.

Pengaruh Ekstrak Daun Kecibeling (Strobilanthes crispa), Kayu Manis (Cinnamon), dan Kersen (Muntingia calabura) Terhadap Indeks Glikemik pada Pengolahan Beras Metode Pratanak 


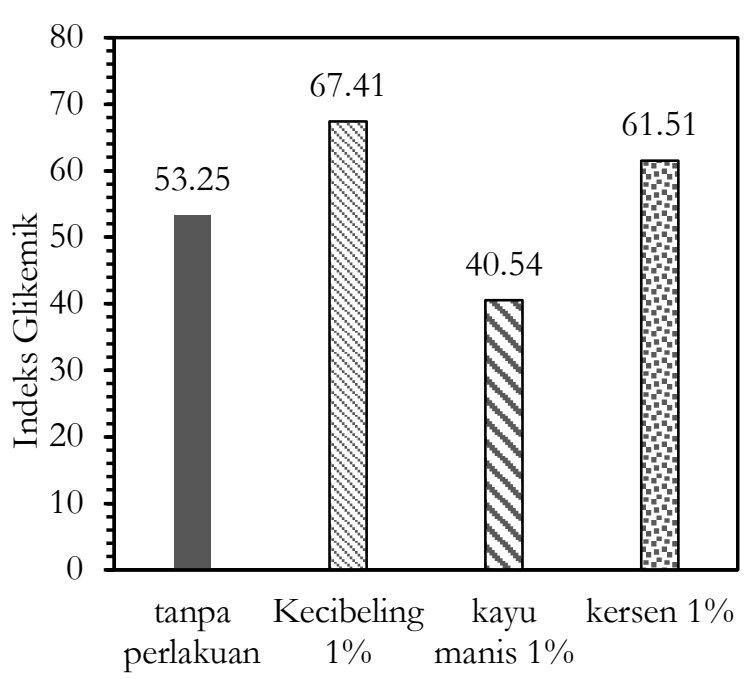

Ekstrak

(a)

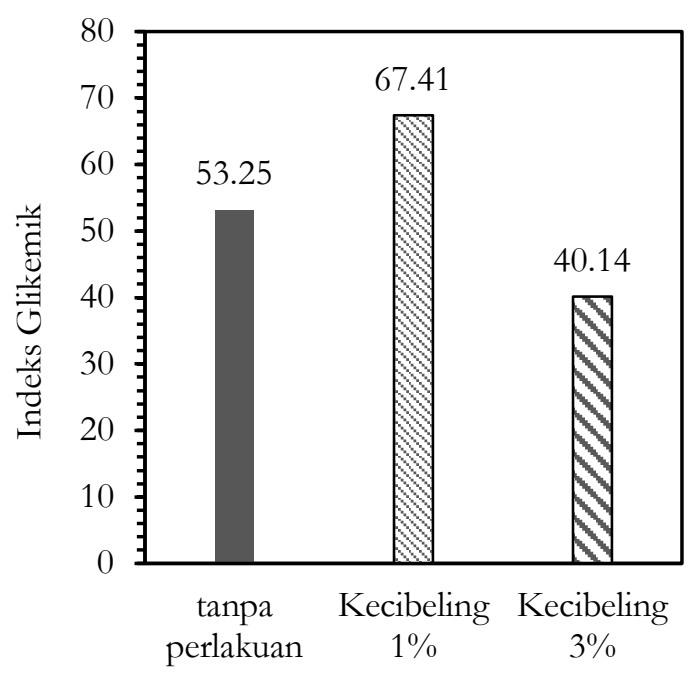

Ekstrak

(b)

Gambar 4. Pengaruh Penambahan Ekstrak Terhadap Indeks Glikemik Beras pada Suhu Pemasakan $116^{\circ} \mathrm{C}$ Selama 15 menit [(a) jenis ekstrak; (b) fraksi ekstrak kecibeling

Gambar 4 menunjukkan bahwa pengolahan beras pratanak menggunakan ekstrak daun kecibeling $1 \%$ menghasilkan beras yang memiliki IG 67,41. Artinya, IG beras ciherang pratanak dengan ekstrak daun kecibeling 1\% mengalami kenaikan dibandingkan beras ciherang tanpa perlakuan (beras sosoh tanpa proses pratanak) yang memiliki IG sebesar 53,25. Hasil yang berbeda didapatkan ketika proses pratanak menggunakan ekstrak daun kecibeling 3\%, yaitu IG beras mengalami penurunan menjadi 40,14. Fenomena ini belum dapat dijelaskan dan memerlukan studi lebih lanjut. Berbeda dengan proses pratanak menggunakan ekstrak daun kecibeling, proses pratanak menggunakan ekstrak kayu manis $1 \%$ mirip dengan proses pratanak menggunakan ekstrak daun kecibeling 3\%, yaitu IG beras pratanak turun menjadi 41,70. Penggunaan ekstrak daun kersen $1 \%$ cenderung menghasilkan produk beras pratanak yang memiliki IG mirip dengan beras pratanak menggunakan ekstrak daun kecibeling 1\%. IG beras ciherang naik hingga 61,51, bahkan lebih tinggi dari beras ciherang tanpa perlakuan. Berdasarkan Gambar 4 maka dapat disimpulkan bahwa penggunaan ekstrak kayu manis memberikan pilihan yang terbaik dibanding ekstrak yang lain. Hanya saja masih perlu dilakukan studi lebih lanjut untuk dapat menjelaskan fenomena yang ditunjukkan oleh Gambar 4.

\section{Kesimpulan}

Proses pengolahan beras pratanak menjadi lebih sederhana jika dilakukan pada beras giling dibandingkan gabah kering. Perendaman beras giling di dalam air suhu $30^{\circ} \mathrm{C}$ membutuhkan waktu 30 menit untuk memperoleh kadar air 30\%. Lama waktu pratanak pada suhu $116^{\circ} \mathrm{C}$ lebih baik dilakukan selama 15 menit, karena mampu menurunkan IG beras ciherang menjadi 40,54. Penggunaan ekstrak kecibeling 3\% dan kayu manis $1 \%$ menghasilkan beras ciherang dengan IG sebesar 40,14 dan 40,54, sementara penggunaan ekstrak daun kecibeling 1\% dan daun kersen 1\% tidak menurunkan IG tetapi naik menjadi lebih dari 60 .

\section{Ucapan Terima Kasih}

Ucapan terima kasih kami sampaikan kepada Rektor Universitas Sebelas Maret yang telah memberikan dukungan atas terlaksananya penelitian ini melalui dana hibah penelitian Penerimaan Negara Bukan Pajak (PNBP) Tahun 2020 skim HGR Pengabdian Masyarakat. 


\section{Referensi}

[1] I.D.F.D. Atlas, International Diabetes Federation, 1955. https://doi.org/10.1016/S01406736(55)92135-8.

[2] World Health Organization, “Global Report on Diabetes," Isbn. 97888 (2016). https://doi.org/ISBN 9789241565257.

[3] D. Mustikawati, E. Erawati, H. Supriyatno, "Effect of the Diabetes Exercise on the Blood Sugar Levels in Diabetes Mellitus Patients," J. Nurs. Care. 3 19-25 (2020).

[4] G. Nantel, "Carbohydrates in human nutrition. Report of a Joint FAO/WHO Expert Consultation.," FAO Food Nutr. Pap. 66 1-140 (1998).

[5] S. Widowati, "PEMANFAATAN EKSTRAK TEH HIJAU (Camellia sinensis O.Kuntze) DALAM PENGEMBANGAN BERAS FUNGSIONAL UNTUK PENDERITA DIABETES MELITUS," (2007). http://repository.ipb.ac.id/handle/123456789/40897.

[6] K. Parastouei, M.E. Shahaboddin, M. Motalebi, S.M. Mirhashemi, A.M. Faraji, F. Seyyedi, "Glycemic index of Iranian rice," Sci. Res. Essays. 6 5302-5307 (2011). https://doi.org/10.5897/SRE11.689.

[7] L.F. Himmah, W. Handayani, M. Si, J. Kimia, F. Matematika, P. Alam, U.J. Unej, J. Kalimantan, "Pengaruh Ekstrak Teh Hijau dalam Pembuatan Beras dengan IG Rendah," 5-7 (n.d.).

[8] J.O. Chung, S.H. Yoo, Y.E. Lee, K.S. Shin, S.J. Yoo, S.H. Park, T.S. Park, S.M. Shim, "Hypoglycemic potential of whole green tea: Water-soluble green tea polysaccharides combined with green tea extract delays digestibility and intestinal glucose transport of rice starch," Food Funct. 10 746-753 (2019). https://doi.org/10.1039/c8fo01936c.

[9] T. Malinski, Z. Taha, S. Grunfeld, S. Patton, M. Kapturczak, P. Tomboulian, "Diffusion of Nitric Oxide in the Aorta Wall Monitored in Situ by Porphyrinic Microsensors," Biochem. Biophys. Res. Commun. 193 1076-1082 (1993). https://doi.org/10.1006/bbrc.1993.1735.

[10] H. Tsuneki, M. Ishizuka, M. Terasawa, J. Bin Wu, T. Sasaoka, I. Kimura, "Effect of green tea on blood glucose levels and serum proteomic patterns in diabetic $(\mathrm{db} / \mathrm{db})$ mice and on glucose metabolism in healthy humans," BMC Pharmacol. 4 1-10 (2004). https://doi.org/10.1186/14712210-4-18.

[11] F. Kurniawati, S. Zaenab, S. Wahyuni, “Atlas Tumbuhan Obat Indonesia,” J. Pendidik. Biol. Indones. 1 148-157 (2015).

[12] H. Nurraihana, N.A. Norfarizan-Hanoon, "Phytochemistry, pharmacology and toxicology properties of Strobilanthes crispus," Int. Food Res. J. 20 2045-2056 (2013).

[13] G. El-Desoky, "Antidiabetic and hypolipidemic effects of Ceylon cinnamon (Cinnamomum verum) in alloxan-diabetic rats," J. Med. Plants Res. 6 1685-1691 (2012). https://doi.org/10.5897/jmpr11.1472.

[14] A. Landani, E. Kurniawaty, "Pengaruh Pemberian Kayu Manis (Cinnamomum cassia) Terhadap Penurunan Gula Darah Pada Penderita Diabetes Melitus The Effect of Giving a Cinnamon (Cinnamomum cassia ) to The Blood Sugar Decrease in People with Diabetes Melitus Type 2,"J Urnal Agromedicine Unila. Volume 5 N 1-5 (2018).

[15] A. Sangal, "Role of cinnamon as beneficial antidiabetic food adjunct: a review," Adv. Appl. Sci. Res. 2 440-450 (2011).

[16] Y.P. Arum, "ISOLASI DAN UJI DAYA ANTIMIKROBA EKSTRAK DAUN KERSEN (Muntingia calabura)," J. MIPA Unnes. 35115048 (2013).

[17] A. Fitriana, PENGARUH PEMBERIAN EKSTRAK ETANOL 70\% DAUN KERSEN (Muntingia calabura L.) TERHADAP PENURUNAN KADAR GULA DARAH TIKUS PUTIH (Rattus norvegicus) YANG DIINDUKSI ALOKSAN, 2019.

[18] R. Rimbawan, L. Amalia, "NILAI INDEKS GLIKEMIK BERBAGAI PRODUK OLAHAN SUKUN (Artocarpus altilis)," J. Giri Dan Pangan. 628 (2011). https://doi.org/10.25182/jgp.2011.6.1.28-35.

[19] R. Hasbullah, E.G. Fadhallah, D.P. Almada, "Teknologi Pengolahan dan Pengembangan Usaha Beras Pratanak," Pros. Semin. Nas. Hasil-Hasil PPM IPB 2016.339-353 (2016).

[20] A. Wiedyastanto, M. Bagas, "Beras Beindek Glikemik Rendah Untuk Penderita Diabetes Melitus," Univ. Sebel. Maret. (2019).

[21] M. Margono, F. Hanifah, A.A. Safitri, B.S.T. Sambodo, P. Paryanto, J. Waluyo, A.D. Susanti, P. Pengaruh Ekstrak Daun Kecibeling (Strobilanthes crispa), Kayu Manis (Cinnamon), dan Kersen 
Setyono, "Menurunkan Indeks Glikemik Beras Putih Melalui Proses Pratanak," Equilib. J. Chem. Eng. 4 (2021). https://doi.org/10.20961/equilibrium.v4i2.45464.

[22] F.A. Afandi, C.H. Wijaya, D.N. Faridah, N.E. Suyatma, "Hubungan antara Kandungan Karbohidrat dan Indeks Glikemik pada Pangan Tinggi Karbohidrat,” Pangan. 28 145-160 (2019). 